Volume 16 (1) (2020) : 23-38
Jurnal Borneo Administrator
p-issn : 1858-0300; e-issn : 2407-6767
http://samarinda.lan.go.id/jba
$\mathrm{DOI}: 10.24258 / j b a . v 16 i 1.623$

\title{
OJREK BARENG: MEMPERDEBATKAN ARGUMEN APATI DALAM PENYELESAIAN MASALAH PUBLIK (STUDI KASUS BANK SAMPAH MALANG)
}

\section{OJREK BARENG: ARGUING THE ARGUMENT OF APATHY IN SOLVING PUBLIC ISSUE (CASE STUDY OF MALANG GARBAGE BANK)}

\author{
Qurnia Indah Permata Sari, Wawan Sobari, dan Sukaesi Marianti \\ Magister IImu Sosial FISIP Universitas Brawijaya \\ Jl. Veteran Malang, Jawa Timur \\ Email: qurniaindahpermatasari@gmail.com; wawansobari@ub.ac.id; \\ marianti.sukaesi@gmail.com
}

Naskah diterima: 30 November 2019; revisi terakhir: 9 Januari 2020; disetujui 18 Februari 2020

How to Cite: Sari, Qurnia Permata S., Sobari, Wawan., dan Marianti, Sukaesi. (2020). OJREK BARENG: Memperdebatkan Argumen Apati dalam Penyelesaian Masalah Publik (Studi Kasus Bank Sampah Malang). Jurnal Borneo Administrator, 16 (1), 23-38. https://doi.org/10.24258/jba.v16i1.623

\begin{abstract}
The dominant argument about the work of Everyday Makers states that apathy encourages community involvement in solving public problems. This qualitative case study aims to explore the workings of the Everyday Makers practice in the case of Malang Garbage Bank management. Unlike the previous argument, this study found an enthusiastic attitude that encouraged the community to work together in handling the waste problem in Malang city. The enthusiastic attitude that drives the community to work with the government and the private sector is the philosophy of Ojrek Bareng which is based on Arek Culture. This philosophy was reflected in the expression of the community in dealing with waste problems, namely sengkuyung seduluran (brotherhood spirit), ewuh pakewuh (uneasy feelings) and tanpo pamrih (sincere). This study debates the workings of Everyday Makers, that what drives the work of Everyday Makers in solving public problems is public's apathy towards the government. However, this study found that Ojrek Bareng as acommunity enthusiasm in solving waste problems through the Malang Garbage Bank. The practical implications of this study were the governance of public issue.
\end{abstract}

Keywords: Everyday Makers, Governance, Malang Garbage Bank

\begin{abstract}
Abstrak
Argumen dominan tentang bekerjanya Everyday Makers menyebutkan bahwa sikap apati mendorong keterlibatan masyarakat dalam menyelesaikan permasalahan publik. Studi kasus kualitatif ini bertujuan mengeksplorasi bekerjanya praktik Everyday
\end{abstract}


Makers dalam kasus pengelolaan Bank Sampah Malang. Berbeda dengan argumen sebelumnya, studi ini menemukan sikap antusias yang mendorong masyarakat untuk bekerjasama dalam penanganan masalah sampah di Kota Malang. Sikap antusias yang mendorong masyarakat untuk bekerjasama dengan pemerintah dan swasta adalah filosofi Ojrek Bareng yang dilandasi oleh Budaya Arek. Filosofi ini tercermin dari ungkapan masyarakat dalam menangani permasalahan sampah yaitu sengkuyung seduluran (semangat persaudaraan), ewuh pakewuh (perasaan tidak enak) dan tanpo pamrih (tanpa pamrih). Studi ini mendebat bekerjanya Everyday Makers, bahwa yang mendorong bekerjanya Everyday Makers dalam menyelesaikan permasalahan publik adalah sikap apati masyarakat terhadap pemerintah. Namun, studi ini menemukan bahwa Ojrek Bareng sebagai bentuk antusiasme masyarakat dalam menyelesaikan masalah sampah lewat Bank Sampah Malang. Implikasi praktis dari studi ini adalah tata kelola masalah publik.

\section{Kata kunci: Everyday Makers, Governance, Bank Sampah Malang}

\section{A. PENDAHULUAN}

Setiap tahun volume sampah di kota besar semakin meningkat, hal tersebut terjadi akibat semakin pesatnya pertumbuhan penduduk dan perubahan pola konsumsi masyarakat (Ratiabriani, Bagus, \& Purbadharmaja, 2016:56). Salah satu kota besar yang terus mengalami peningkatan volume sampah ialah Kota Malang. Pertumbuhan jumlah penduduk, populasi ruko, perumahan dan minimarket yang sangat pesat di Kota Malang menjadi faktor utama semakin naiknya volume sampah. Menurut Dinas Lingkungan Hidup Kota Malang pada tahun 2019 jumlah sampah per hari yang disisakan oleh masyarakat Kota Malang sebanyak 670 ton, sedangkan jumlah sampah yang terangkut ke Tempat Pembuangan Akhir (TPA) sebanyak 503 ton per hari (Dinas Lingkungan Hidup Kota Malang, 2019).

Timbulan sampah Kota Malang setiap harinya mencapai $2.271 \mathrm{~m} 2$ sedangkan luas TPA Supiturang 15 hektar (Sujiyanto, 2016:118), apabila semua sampah diangkut dan dibuang ke TPA Supiturang lama kelamaan TPA Supiturang akan penuh, seperti yang terjadi pada 4 TPA yang sudah tutup sebelumnya. TPA yang sudah tutup tersebut adalah TPA Pandanwangi, TPA Gadang, TPA Lowokdoro dan TPA Simpang Majapahit (Arief, 2013:204). Apabila TPA Supiturang sudah tutup ditengah pertumbuhan Kota Malang yang begitu pesat, akan sangat sulit untuk menyediakan lahan bagi TPA baru. TPA yang baru letaknya harus jauh dari pemukiman penduduk, hal ini disebabkan oleh sering kali terjadi penolakan masyarakat terhadap pembukaan lahan baru untuk TPA. Pembukaan lahan baru juga membutuhkan biaya yang sangat mahal, selain untuk membeli tanah bagi pembukaan lahan baru juga untuk menyediakan peralatan untuk menunjang operasional TPA baru.

Apabila sampah dapat dikelola dengan baik, sampah akan menjadi sumber pendapatan yang dapat memberdayakan masyarakat. Sistem pengelolaan sampah yang mendorong masyarakat untuk secara kolektif berperan aktif sekaligus dapat memberdayakan masyarakat adalah bank sampah. Kota Malang merupakan kota yang berhasil mereduksi limbah sampahnya dengan bantuan Bank Sampah. Bank Sampah Malang mampu mengelola 20-30 persen sampah per hari dari total 670 ton sampah yang dibawa ke TPA (Setyono, 2019). Bank Sampah Malang juga merupakan salah satu bank sampah terbaik yang ada di Indonesia menurut Pemerintah Pusat dan Menteri Lingkungan Hidup (Hakim, 2017; Hariyanto, 2017). Terdapat tiga aktor yang bekerja sama dalam Bank Sampah Malang yaitu pemerintah, masyarakat dan swasta.

Anggapan Bank Sampah Malang adalah Everyday Makers sesuai konsep Everyday Makers yang dikemukakan oleh Bang dan Eva bahwa Bank Sampah Malang merupakan 
warga sipil yang berada di luar otoritas publik yang bertindak di ruang publik atas dasar keperhatinan terhadap lingkungan yang semakin dipenuhi oleh sampah. Bank Sampah Malang merupakan sebuah praktik unik untuk mengurangi volume sampah yang ada di Kota Malang. Bank Sampah Malang memfasilitasi pemerintah, masyarakat, dan swasta untuk secara bersama-sama menangani permasalahan sampah.

Secara teori Everyday Maker masuk dalam topik citizenship dalam kajian governance menurut Mark Bevir (2012:XV). Di dalam teori governance, Everyday Makers masuk dalam Decentered Theory. Decentered Theory menolak gagasan bahwa hanya terdapat satu teks, institusi atau serangkaian peristiwa yang tunggal, alami, dan tidak dapat disangkal. Pendekatan Decentered Theory menginterpretasikan suatu peristiwa dari berbagai sudut pandang. Menurut Mark Bevir dan Rhodes, tindakan seseorang tidak bergantung pada institusi, praktik, atau sosialisasi. Tindakan yang dilakukan oleh masyarakat bergantung pada keyakinan yang mereka pegang. Keyakinan itu dipengaruhi oleh tradisi atau kepercayaan masyarakat. Masyarakat Kota Malang memegang teguh filosofi Ojrek Bareng yang mendorong masyarakat untuk ikut serta dalam menangani masalah sampah bersama pemerintah dan swasta.

Penulis berusaha untuk melihat penerapan konsep Everyday Makers di Indonesia khususnya Kota Malang yang memiliki perbedaan setting sosial, budaya dan ekonomi yang berbeda dengan Denmark lokasi penelitian Bang dan Eva. Berbeda dengan studi Bang dan Eva, studi ini menemukan adanya sikap antusias masyarakat untuk bekerja sama dalam penanganan masalah sampah di Kota Malang. Masyarakat bekerja sama dengan pemerintah dan swasta untuk menangani permasalahan sampah. Bank Sampah Malang lahir dengan tujuan untuk memfasilitasi ketiga aktor governance yaitu pemerintah, masyarakat dan swasta untuk secara bersama-sama menangani permasalahan utama Kota Malang yaitu sampah.

Berikut penjabaran dari masing-masing aktor tersebut, Pertama, pemerintah adalah Dinas Lingkungan Hidup Kota Malang, Kedua, masyarakat adalah pengurus Bank Sampah Malang, pengurus bank sampah unit, Ketiga, swasta adalah CSR PT. PLN. Bank Sampah Malang merupakan sebuah praktik unik untuk mengurangi volume sampah yang ada di Kota Malang. Berbeda dengan Denmark selaku lokasi penelitian Bang dan Eva, bahwa yang mendorong keterlibatan masyarakat dalam menyelesaikan permasalahan publik adalah sikap apati masyarakat terhadap pemerintah. Penelitian ini penting untuk mengeksplorasi filosofi Ojrek Bareng sebagai faktor yang mendorong masyarakat untuk bekerja sama dengan Pemerintah dan Swasta dalam menangani masalah sampah di Kota Malang. Studi ini bertujuan mengeksplorasi cara kerja Everyday Makers dalam kasus pengelolaan Bank Sampah Malang yang memiliki perbedaan setting sosial, budaya dan ekonomi yang berbeda dengan Denmark lokasi penelitian Bang dan Eva.

\section{B. METODE PENELITIAN}

Penelitian ini dilakukan di Bank Sampah Malang, menggunakan pendekatan kualitatif dengan metode studi kasus. Dalam konteks metodologi dalam riset governance Everyday Makers masuk dalam Interpretive Theory (Bevir, 2012:XIX). Cara pengumpulan data yang digunakan adalah wawancara mendalam, rekaman arsip, dan dokumentasi. Metode analisis data yang digunakan adalah penjodohan pola. Penulis pada mulanya melihat penerapan konsep Everyday Makers di Indonesia khususnya Kota Malang yang memiliki perbedaan setting sosial, budaya dan ekonomi yang berbeda dengan Denmark lokasi penelitian Bang dan Eva. Penulis melihat terdapat kemiripan antara di Indonesia dan Denmark terkait adanya gerakan sosial yang mendorong masyarakat untuk menyelesaikan permasalahan publik. Penulis melihat di Indonesia, khususnya Kota Malang memiliki perbedaan setting 
sosial, budaya, dan ekonomi yang berbeda dengan Denmark, lokasi penelitian Bang dan Eva. Pemerintah Kota Malang sadar bahwa tidak mampu mengurangi sampah sendiri tanpa bantuan dari masyarakat sehingga perlu dilakukan kerja sama antara pemerintah, swasta, dan masyarakat untuk menyelesaikan permasalahan sampah yang ada di Kota Malang. Bank Sampah Malang hadir sebagai sebuah solusi untuk memfasilitasi ketiga komponen tersebut untuk menyelesaikan permasalahan publik, yaitu sampah.

Penelitian ini menggunakan purposive sampling sebagai teknik pengambilan sampel. Informan yang diwawancarai berjumlah 7 orang yang memiliki pemahaman langsung dengan masalah penelitian. Informan yang diwawancarai adalah Sekretaris Daerah Kota Malang, Kepala Bidang Bina Kemitraan dan Pengendalian Lingkungan Dinas Lingkungan Hidup Kota Malang, Badan Pengawas dan Stok Gudang Bank Sampah Malang, Asisten Manager CSR. PT. PLN Distribusi Jawa Timur, pengurus Bank Sampah Unit Zaira, pengurus Bank Sampah Unit Gurih dan pengurus Bank Sampah Unit Mitra Mandiri.

Rekaman arsip yang digunakan adalah rekaman pemaparan seminar terkait inovasi asuransi kesehatan dengan membayar sampah oleh dr. Gamal Albinsaid dalam acara Seminar Dear Millennial, Let's Move on For Better Future pada tanggal 31 Oktober 2019 di Masjid Raden Patah Universitas Brawijaya Malang. Dokumen yang digunakan dalam penelitian ini adalah neraca pengurangan dan penanganan sampah rumah tangga dan sampah sejenis sampah rumah tangga, presentasi pengelolaan sampah oleh Dinas Kebersihan dan Pertamanan Kota Malang, presentasi pembinaan pengelolaan sampah 3R melalui bank sampah, dan presentasi materi Bank Sampah Malang dan wisata lingkungan.

\section{KERANGKA TEORI}

Everyday Makers merupakan warga sipil yang berada di luar otoritas publik, baik pemerintah maupun institusi publik, yang bertindak di ruang publik atas dasar proyeksi atau tujuan yang mereka sukai, atau berdasarkan keprihatinan yang mereka rasakan (Bang \& Eva, 1999:326). Secara historis, Everyday Makers pertama kali dikemukakan oleh Henrik Paul Bang dan Eva (1999) dalam kajian keterlibatan politik masyarakat akar rumput di Innerebo, Kopenhagen, Denmark, yang memiliki tradisi perlawanan dan bersikap apati pada otoritas publik, baik pemerintah maupun politisi di lembaga perwakilan, karena tidak mampu menyelesaikan permasalahan publik. Otoritas publik maupun politisi di lembaga perwakilan dianggap tidak responsif dan hanya mengejar ambisi dan kepentingan pribadi dengan mengatasnamakan rakyat (Bang \& Eva, 1999:325-340).

Sikap apati tersebut ditunjukkan oleh masyarakat dengan menurunnya tingkat partisipasi masyarakat pada pemilihan umum dan menurunnya keanggotaan pada partai politik (Dalton, 2008:19-37). Sikap apati masyarakat kepada pemerintah inilah yang mendorong Everyday Makers berorientasi pada penyelesaian masalah sosial sehari-hari yang ada di lingkungan mereka secara konkret, selain itu sebagai sebuah protes simbolik, karena kinerja pemerintah tidak memenuhi harapan dari masyarakat (Bang, 2009:100). Pemerintah di negara yang demokratis seharusnya tidak hanya mempertimbangkan tuntutan warganya, namun juga bertindak dengan efektif untuk merespons tuntutan tersebut (Fenwick \& McMillan, 2010:168). Bang dan Eva bahkan meyakinkan agar Everyday Makers berjuang untuk melawan sistem atau dominasi negara (dalam Newman, 2005:16).

Berbeda dengan studi Bang dan Eva, studi ini menemukan sikap antusias masyarakat untuk bekerja sama dalam penanganan masalah sampah di Kota Malang. Masyarakat bekerja sama dengan pemerintah dan swasta untuk menangani permasalahan sampah di Kota Malang. Keterlibatan masyarakat dalam penyelesaian masalah publik di Denmark (lokasi penelitian Bang dan Eva) juga dipengaruhi oleh sikap individualis masyarakat Denmark. Sikap 
individualis tersebut tercermin pada proyeksi Everyday Makers menyelesaikan masalah publik tersebut karena bersentuhan dengan individu yang tergabung dalam kelompok Everyday Makers (Bang, 2010:180). Bertolak belakang dengan penelitian ini bahwa sengkuyung seduluran (semangat persaudaraan) adalah salah satu nilai dalam filosofi Ojrek Bareng yang mendorong masyarakat untuk bekerja sama dengan pemerintah dan swasta dalam menangani masalah publik yaitu sampah.

Everyday Makers lebih tertarik pada proses tata kelola yang memiliki relevansi langsung untuk kehidupan sehari-hari mereka dibandingkan ikut terlibat dalam politik praktis, misalnya di lingkungan sekitar mereka, di tempat kerja mereka dengan cara mereka sendiri, dan sumber daya yang mereka punya (Bang \& Eva, 1999:337). Bank Sampah adalah sebuah sistem yang secara kolektif mengelola sampah padat dan mendorong masyarakat untuk berpartisipasi secara aktif di dalamnya sistem bank sampah bekerja dengan cara menampung sampah, memilah sampah dan menyalurkan sampah kepada pasar agar masyarakat mendapatkan keuntungan ekonomi (Prasetyo \& Arifin, 2017:78). Salah satu Bank Sampah terbaik menurut Pemerintah Pusat adalah Bank Sampah Malang (Hariyanto, 2017).

Everyday Makers tidak tertarik pada keterlibatan politik yang abstrak ataupun ideologis, tetapi keterlibatan mereka didorong oleh perasaan akan kebutuhan dan tanggung jawab untuk membantu menyelesaikan permasalahan konkret yang ada di sekitar mereka dengan pengalaman yang mereka punya (Newman, 2005:5). Sebagian besar Everyday Makers tidak berpartisipasi langsung dalam politik formal karena tidak terdapat mekanisme yang dapat mewakili mereka dalam proses kebijakan. Meskipun mereka memiliki suara tetapi tidak akan mampu untuk memengaruhi hasil, sehingga mereka memilih untuk terlibat dalam menyelesaikan permasalahan publik di sekitar mereka (Bochel, Bochel, Somerville, \& Worley, 2008:203). Penulis menganggap Bank Sampah Malang adalah Everyday Makers, karena sesuai konsep Everyday Makers yang dikemukakan oleh Bang dan Eva, bahwa Bank Sampah Malang merupakan warga sipil yang berada di luar otoritas publik yang bertindak di ruang publik atas dasar keprihatinan terhadap lingkungan yang semakin dipenuhi oleh sampah. Bank Sampah Malang merupakan sebuah praktik unik untuk mengurangi volume sampah yang ada di Kota Malang. Bank Sampah Malang memfasilitasi pemerintah, masyarakat, dan swasta untuk secara bersama-sama menangani permasalahan sampah.

Menurut Bang \& Eva terdapat beberapa cara yang dilakukan oleh Everyday Makers untuk berpartisipasi dalam penyelesaian masalah publik, Pertama, lakukan di mana pun anda berada dengan motif untuk bersenang-senang ataupun karena kebutuhan, Kedua, lakukan secara penuh waktu ataupun paruh waktu, Ketiga, lakukan dengan percaya diri, Keempat, lakukan secara konkret untuk pemecahan masalah umum dan Kelima, lakukan dengan sistem jika dibutuhkan (Bang \& Eva, 1999:336).

\section{HASIL DAN PEMBAHASAN}

\section{Tinjauan Kultural Masyarakat Kota Malang}

Kota Malang memiliki luas $110.06 \mathrm{~km}^{2}$. Terdiri atas 57 Kelurahan, 536 unit RW dan 4.011 unit RT (Badan Pusat Statistik, 2016:33-35). Jumlah penduduk Kota Malang sampai tahun 2018 sebesar 866.118 (Badan Pusat Statistik, 2019:5-6). Masyarakat yang tinggal di Kota Malang berasal dari beragam suku dan budaya, mayoritas adalah Suku Jawa, kemudian diikuti oleh suku-suku mayoritas lain seperti Suku Madura, Suku Arab dan Suku Tionghoa (Putra, 2012). Menurut Hotman Siahaan, Kota Malang merupakan salah satu yang tergabung dalam Budaya Arek (Zuhro, 2009:42). Budaya Arek memiliki ciri khas lebih 
terbuka, ekspresif, bloko suto (terus terang) dan tidak ewuh pakewuh terhadap sesuatu. Oleh sebab itu, dalam menyampaikan aspirasinya masyarakat Jawa Timur pada umumnya terbiasa menyampaikan secara terang-terangan dan bahkan terkesan keras (Zuhro, 2009:44).

Partisipasi masyarakat dalam suatu kegiatan yang tergabung dalam Budaya Arek cenderung tinggi (Zuhro, 2009:94). Hampir serupa dengan apa yang dikatakan oleh Zuhro, menurut Yuliti, masyarakat dalam Budaya Arek dikenal memiliki sifat egaliter, terbuka, demokratis dan memiliki solidaritas yang tinggi (Sungkowati, 2019:165). Masyarakat yang tergabung di Budaya Arek juga memiliki keberanian dan kenekatan dalam melakukan sesuatu. Hal ini merupakan hasil dari akulturasi Budaya Madura ke Budaya Arek, sehingga yang tergabung di Budaya Arek mencontoh keberanian dan kenekatan orang-orang Madura (Goenawan, Kuntjara, \& Pratama, 2016).

Menurut Abdillah, pengalaman yang dimiliki seseorang menjadi perhatian utama yang selalu diingat, meskipun hanya pengalaman kecil. Pengalaman ini digunakan sebagai acuan untuk memecahkan persoalan sehari-hari. Hal inilah yang menjadi kunci relasi manusia dan alam dalam masyarakat yang tergabung di Budaya Arek (Abdillah, 2007:72). Selain ciri-ciri tersebut, Masyarakat Kota Malang memiliki ciri khas yang berbeda dengan masyarakat yang tergabung dalam Budaya Arek yang lain. Masyarakat Kota Malang memiliki bahasa tersendiri yang disebut Bahasa Malangan. Salah satu ciri khas yang membedakan antara Bahasa Arek Surabaya dan Arek Malang adalah penggunaan bahasa terbalik yang lazim dipakai oleh Arek-Arek Malang. Bahasa terbalik Malangan ini sering disebut sebagai bahasa walikan atau osob kiwalan. Bahasa Malangan berfungsi sebagai pembeda Arek Malang dengan masyarakat Jawa lain dan sebagai identitas bagi warga Malang (Hanggoro, 2016:23). Penggunaan bahasa tersebut dilakukan dengan cara membalikkan setiap kata dalam kalimat, sedangkan struktur kalimatnya tetap seperti aslinya. Namun, tidak semua kata dapat dibalik, seperti misalnya kata yang terdapat bunyi (ny) dan (ng) (Hanggoro, 2016:20-24). Kata Ojrek Bareng adalah osob kiwalan dari kerjo bareng (kerja bersama). Filosofi Ojrek Bareng mengandung makna bahwa pemerintah, masyarakat dan swasta saling bekerja sama untuk menangani permasalahan sampah di Kota Malang.

\section{Bank Sampah Malang sebagai fasilitator bagi aktor Governance}

Bank Sampah Malang merupakan sebuah lembaga berbadan hukum koperasi yang didirikan atas kerja sama antara Pemerintah Kota Malang melalui Dinas Kebersihan dan Pertamanan Kota Malang dan CSR PT PLN yang diresmikan pada tanggal 15 November 2011 (Bank Sampah Malang, 2018). Bank Sampah Malang memiliki sistem manajerial seperti halnya bank konvensional, tetapi kegiatan operasional sehari-harinya dilakukan oleh masyarakat dan yang ditabung bukanlah uang melainkan sampah (Utami, 2013:3). Bank Sampah Malang memiliki struktur organisasi inti yang bertugas untuk melakukan kegiatan operasional sehari-hari Bank Sampah Malang. Berikut ini adalah struktur organisasi inti Bank Sampah Malang: 


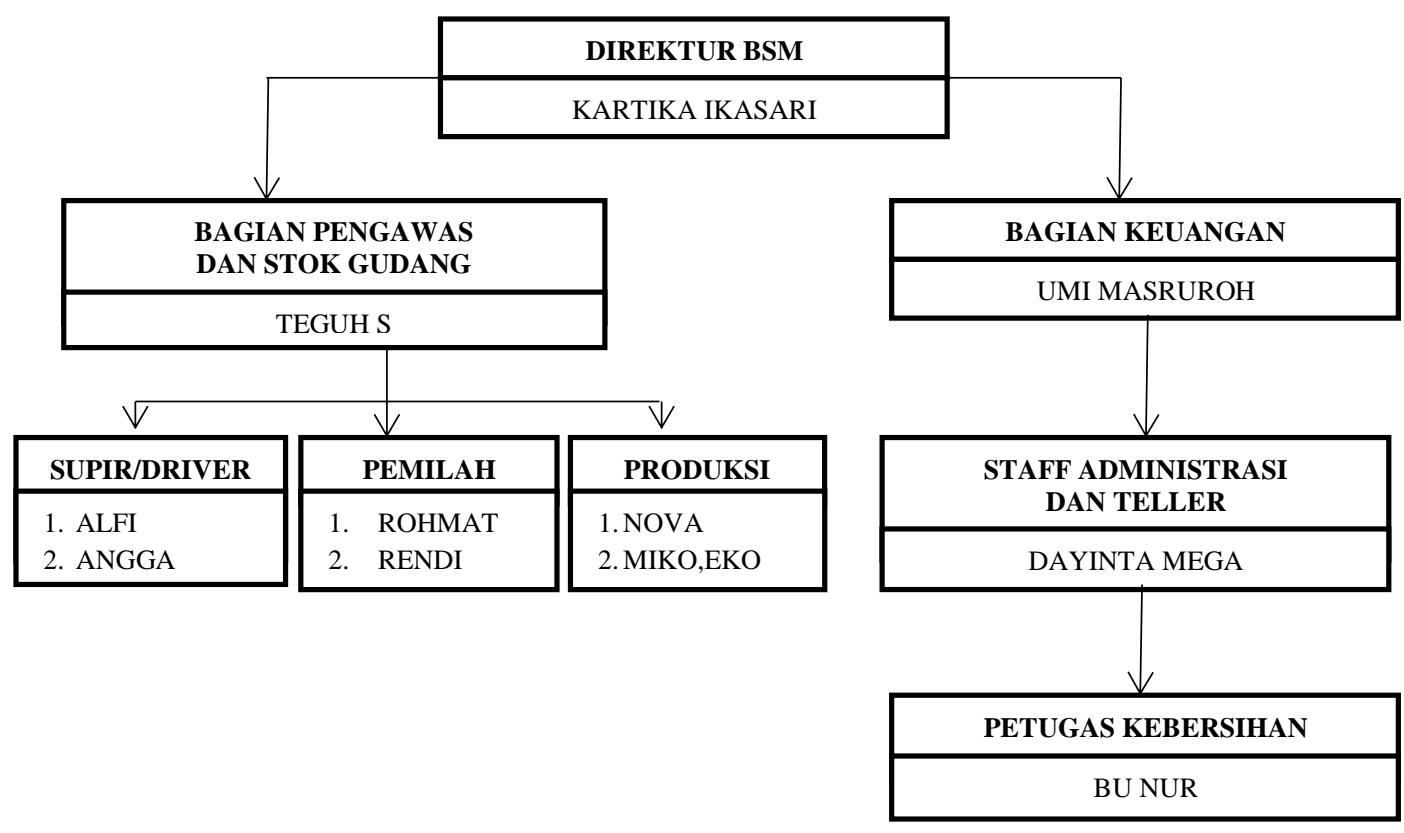

Gambar 1.

Struktur Organisasi Bank Sampah Malang (Sumber: Bank Sampah Malang, 2019)

Bank Sampah Malang memiliki berbagai macam produk, antara lain 70 jenis sampah terpilah, kompos, hasil cacahan plastik, hasil budidaya cacing, biogas dan kerajinan daur ulang sampah. Bank Sampah Malang mendorong masyarakat Kota Malang untuk mandiri dalam pengelolaan sampah dilihat dari biaya operasional yang dapat dibiayai sendiri oleh setiap nasabah Bank Sampah Malang. Dampak dari adanya Bank Sampah Malang ini tidak hanya sekadar untuk mengurangi sampah yang terkumpul di gerobak sampah, tetapi juga memberdayakan masyarakat dan menguatkan peran perempuan dalam skala rumah tangga ataupun dalam lingkup komunitas nasabah Bank Sampah Malang.

Bank Sampah Malang hadir dengan tujuan untuk memfasilitasi ketiga komponen governance, yaitu pemerintah, masyarakat, dan swasta untuk secara bersama-sama menangani permasalahan utama masyarakat, yaitu sampah. Penulis menganggap Bank Sampah Malang sebagai Everyday Makers sesuai konsep Everyday Makers yang dikemukakan oleh Bang dan Eva, bahwa Bank Sampah Malang merupakan warga sipil yang berada di luar otoritas publik yang bertindak di ruang publik atas dasar keprihatinan terhadap lingkungan yang semakin dipenuhi oleh sampah, selain itu partisipasi Bank Sampah Malang dalam penyelesaian permasalahan publik sesuai dengan indikator cara yang dilakukan Everyday Makers dalam penyelesaian masalah publik yang dikemukakan oleh Bang dan Eva. Berikut cara yang digunakan oleh Bank Sampah Malang untuk menyelesaikan permasalahan publik.

Pertama, lakukan dimanapun anda berada dengan motif untuk bersenang-senang ataupun karena kebutuhan. Setiap hari Bank Sampah Malang dapat mengelola sampah sebanyak 4,5 ton per hari. Bank Sampah Malang juga memasarkan hasil dari kegiatan pengelolaan sampah kepada pihak industri. Petugas dari Bank Sampah Malang memilih harga termahal yang ditawarkan oleh pihak industri agar masyarakat semakin bersemangat untuk memilah dan menabung sampah di Bank Sampah Malang. Meskipun begitu, terdapat fluktuasi harga sampah menyesuaikan harga yang ada di pasaran (Purwanto, Destiani, \& 
Partono, 2012:3). Harga sampah akan terus diperbarui setiap dua minggu sekali oleh Bank Sampah Malang mengikuti harga pasar.

Kedua, lakukan secara penuh waktu ataupun paruh waktu. Bank Sampah Malang buka pada hari Senin hingga Sabtu pada pukul 08.00 sampai pukul 16.00. Bank Sampah Malang juga bersedia untuk mengambil sampah ke nasabah apabila sampah yang dikumpulkan telah mencapai $50 \mathrm{~kg}$, sesuai jadwal yang disepakati.

Ketiga, lakukan dengan percaya diri. Bank Sampah Malang memberikan pelatihan pemilahan sampah dan kerajinan daur ulang kepada masyarakat untuk mengelola sampah anorganik dan sampah nonorganik agar menjadi lebih bernilai. Bank Sampah Malang juga bersedia untuk memberikan kegiatan workshop yang dapat dilakukan di tempat ataupun di lokasi lain sesuai dengan kegiatan-kegiatan yang dilakukan masyarakat.

Keempat, lakukan dengan konkret untuk pemecahan masalah umum. Bank Sampah Malang berhasil mengurangi sampah yang dibawa ke TPA.

Kelima, lakukan dengan sistem jika dibutuhkan. Bank Sampah Malang masih tidak memiliki gedung sendiri untuk operasional sehari-hari. Saat ini Bank Sampah Malang masih menyewa gedung dari Pemerintah Kota Malang dan membayar biaya sewa tersebut setiap bulan. Pemerintah Kota Malang memberikan bantuan berupa potongan biaya sewa kepada Bank Sampah Malang.

\section{Nilai-nilai dalam Filosofi Ojrek Bareng dalam Penanganan sampah di Kota Malang}

Secara kultural Ojrek Bareng bermakna bahwa pemerintah, masyarakat dan swasta saling bahu-membahu untuk menangani permasalahan sampah. Filosofi Ojrek Bareng muncul dalam bahasa tiap-tiap aktor Governance sebagai berikut. Pemerintah Kota Malang menyadari bahwa mereka memiliki keterbatasan dalam menyelesaikan permasalahan publik, baik dari segi pendanaan, segi sumber daya manusia maupun dalam segi infrastruktur, sehingga pemerintah mengajak masyarakat dan swasta yaitu CSR PT PLN untuk bersamasama berpartisipasi di Bank Sampah Malang dengan tujuan untuk mengurangi sampah yang di bawa ke TPA Supiturang.

Hal di atas sesuai dengan kajian Goldsmith dan Eggers bahwa pemerintah dalam hal menyelesaikan permasalahan publik tidak selalu memiliki sumber daya yang memadai (Goldsmith \& Eggers, 2004: 3-5). Keterbatasan akan sumber daya tersebut menyebabkan Pemerintah Kota Malang menyebabkan Pemerintah Kota Malang mengajak pihak lain yaitu masyarakat dan swasta untuk menangani masalah sampah yang ada di Kota Malang.

Dalam Bank Sampah Malang Pemerintah Kota Malang memiliki peran sebagai berikut. Pertama, pasca pengesahan Bank Sampah Malang oleh Walikota Malang pada tanggal 16 Agustus 2011, Pemerintah Kota Malang membantu Bank Sampah Malang dalam pengurusan perijinan yaitu Ijin Gangguan/HO, SIUP, TDP dan IUI. Kedua, memberikan potongan biaya sewa bangunan untuk kegiatan operasional sehari-hari Bank Sampah Malang. Ketiga, pada tahun 2011 Pemerintah Kota Malang memberikan hibah sebesar Rp 250 juta kepada Bank Sampah untuk biaya operasional awal. Biaya tersebut digunakan oleh Bank Sampah Malang untuk membeli mesin pencacah plastik, agar nilai jual sampah menjadi lebih tinggi daripada sebelum plastik diolah menggunakan mesin pencacah plastik. Keempat, memberikan bantuan berupa timbangan kepada Unit Bank Sampah Malang. Kelima, memberikan pembinaan kepada nasabah Bank Sampah Malang secara continue terkait dengan pengelolaan sampah dengan 3R (Reduce, Reuse, Recycle) kepada nasabah Bank Sampah Malang. Keenam, Pemerintah Kota Malang memberikan pelatihan daur ulang sampah anorganik kepada nasabah Bank Sampah Malang. Ketujuh, Pemerintah Kota Malang melalui Dinas Lingkungan Hidup Kota Malang, Dinas Sosial Kota Malang dan Dinas 
Pariwisata Kota Malang bekerja sama untuk memasarkan hasil kerajinan dari Bank Sampah Malang. Pada saat Pemerintah Kota Malang mengadakan seminar atau kegiatan maka oleholeh yang diberikan oleh Pemerintah Kota Malang kepada peserta adalah kerajinan daur ulang yang berasal dari Bank Sampah Malang. Seperti misalnya pada saat ini Bank Sampah Malang menerima 1000 tas untuk acara pelatihan, maka oleh Bank Sampah Malang pesanan tersebut diberikan kepada nasabah Bank Sampah Malang. Dalam setahun Pemerintah Kota Malang memesan kerajinan daur ulang dari Bank Sampah Malang sebanyak 2 kali untuk mengadakan pelatihan-pelatihan ataupun acara lain yang dilakukan oleh Pemerintah Kota Malang. Kesembilan, pada acara Kemah Hijau yang digelar pada tanggal 27 Juli 2019 hingga 28 Juli 2019, Dinas Lingkungan Hidup Kota Malang memamerkan beberapa karya dari Bank Sampah Malang, seperti tas daur ulang, topeng, olahan daur ulang botol dan kertas bekas. Di acara tersebut Dinas Lingkungan Hidup Kota Malang juga membagikan voucher kepada para peserta Kemah Hijau yang dapat ditukar dengan souvenir, dengan syarat peserta harus menukarnya dengan sampah plastik yang telah peserta kumpulkan.

Masyarakat terlibat di Bank Sampah Malang dengan tujuan agar Kota Malang menjadi bersih, lebih tertata dan sampah yang di bawa ke TPA Supiturang menjadi berkurang. Sikap antusias yang dimiliki oleh masyarakat Kota Malang mendorong masyarakat untuk bekerja sama dalam penanganan masalah sampah di Kota Malang. Sikap antusias masyarakat Kota Malang ini dilandasi oleh Budaya Arek. Bentuk antusias masyarakat tersebut adalah filosofi Ojrek Bareng yang tercermin dalam ungkapan sengkuyung seduluran (semangat persaudaraan), ewuh pakewuh (perasaan tidak enak) dan tanpo pamrih (tanpa pamrih) dalam menangani sampah di Kota Malang.

Sikap antusias masyarakat terhadap sampah juga ditunjukkan dengan kemampuan masyarakat untuk mengelola sampah menjadi bahan yang dapat dimanfaatkan kembali. Masyarakat menggunakan pengalaman yang mereka miliki untuk menangani masalah sampah. Pengalaman yang dimiliki oleh masyarakat yang tergabung dalam Budaya Arek digunakan sebagai acuan untuk memecahkan persoalan sehari-hari (Abdillah, 2007:72). Pengalaman mengolah sampah menjadi suatu barang yang lebih bernilai digunakan sebagai acuan untuk menangani permasalahan sampah yang ada di Kota Malang. Sampah tersebut diolah menjadi berbagai macam kerajinan daur ulang seperti tas, baju, tempat tisu, topeng, kotak pensil, tong sampah, dan beragam bentuk kerajinan lainnya.

Sikap tanpo pamrih masyarakat ditunjukkan dengan bersedia menjadi relawan yang bersedia mengorbankan biaya dan pikiran untuk menjadi pengurus Unit Bank Sampah Malang, serta rela mengorbankan waktu dan tenaga untuk mengumpulkan sampah yang telah dipilah oleh masyarakat Kota Malang. Relawan ini secara ikhlas membantu menangani sampah tanpa mengharapkan imbalan apa pun dari Pemerintah Kota Malang. Relawan tersebut disebut sebagai pengurus Unit Bank Sampah Malang. Sikap tanpo pamrih tersebut tercermin dalam perkataan pengurus Unit Bank Sampah Malang sebagai berikut, "Memang mulai awal kami itu nggak mikir dapat bayaran atau tidak dengan menjadi pengurus unit ini, niat kami sukarela dan Lillahita'ala (komunikasi personal dengan pengurus Bank Sampah Unit Mitra Mandiri, 16 November 2019). Everyday Makers lebih tertarik pada proses tata kelola yang memiliki relevansi langsung untuk kehidupan sehari-hari mereka dibandingkan ikut terlibat dalam politik praktis, misalnya di lingkungan sekitar mereka, di tempat kerja mereka dengan cara mereka sendiri dan sumber daya yang mereka punya.

Nilai egaliter dalam masyarakat yang tergabung di Budaya Arek merupakan salah satu kata kunci terjadinya upaya saling menghargai dan menghormati. Meskipun masyarakat memiliki latar belakang yang berbeda tetapi mereka tetap menjunjung tinggi nilai solidaritas. Nilai solidaritas yang dimiliki oleh masyarakat dapat digunakan untuk mendekatkan 
hubungan antar masyarakat agar tercipta kerukunan dan keharmonisan dalam masyarakat. Salah satu wujud keberhasilan masyarakat dalam menata wilayahnya menjadi lebih indah adalah masyarakat RW 3, Kelurahan Sukun. Masyarakat tersebut bekerja sama dengan didorong oleh nilai sengkyung seduluran (semangat persaudaraan) dalam menangani masalah sampah. Secara bersama-sama masyarakat berkomitmen untuk tidak meminta timbal balik uang dari sampah yang mereka setorkan ke Bank Sampah Unit Gurih. Keputusan tersebut dibuat secara demokratis melalui musyawarah yang dihadiri oleh masyarakat dalam suatu acara pertemuan warga.

Keputusan yang dibuat secara demokratis tersebut membuktikan bahwa masyarakat rela menerima pendapat orang lain yang berbeda pandangan dengan sikap arif dan bijaksana, sehingga mudah dicapai sebuah kesepakatan yang mengikat seluruh masyarakat. Hingga pada akhirnya diperoleh kesepakatan bahwa sampah yang masyarakat setorkan tersebut mereka wujudkan untuk kelestarian lingkungan dan memperindah Kota Malang, khususnya di RW. 3, Kelurahan Sukun. Masyarakat yang tergabung di Budaya Arek juga memiliki keberanian dan kenekatan dalam melakukan sesuatu (Gunawan, Kuntjara, \& Pratama, 2016: 4), dari hasil penjualan sampah yang masyarakat kumpulkan masyarakat membeli bunga serta batu terapi.

Menurut Siti Zuhro, salah satu ciri khas Budaya Arek tidak ewuh pakewuh (perasaan tidak enak) terhadap sesuatu, tetapi berbeda dengan apa yang penulis temukan di lapangan bahwa sikap ewuh pakewuh masih ditunjukkan oleh nasabah bank sampah unit kepada pengunjung yang datang untuk mengunjungi Kampung Terapi. Sikap tersebut ditunjukkan dari pengurus bank sampah unit, berikut pernyataan dari pengurus Bank Sampah Unit Gurih:

"Masyarakat di sini ewuh pakewuh (merasa tidak enak) dengan pengunjung yang datang kesini mbak kalau lingkungan sekitar sini nggak bersih, pengunjung kesini selain mau olahraga dengan batu terapi, kan juga banyak yang mau beli bunga milik warga" (komunikasi personal dengan pengurus Bank Sampah Unit Gurih, pada tanggal 08 November 2019)

Partisipasi masyarakat yang tergabung dalam Budaya Arek cenderung tinggi dalam suatu kegiatan yang berkaitan dengan urusan publik (Zuhro, 2009:94). Hal tersebut tercermin dengan antusiasme masyarakat yang tergabung dalam Bank Sampah Malang. Saat ini nasabah Bank Sampah Malang berjumlah 32.000. Dari jumlah keseluruhan nasabah sebesar 32.000 nasabah, 80 persen adalah Masyarakat Kota Malang, sedangkan 20 persen sisanya adalah Masyarakat Kabupaten Malang dan Kota Batu. Bank Sampah Malang juga memiliki unit yang telah tersebar di berbagai daerah di Kota Malang. Pada tahun 2017 jumlah unit Bank Sampah Malang adalah sebagai berikut, 594 unit milik masyarakat, 264 unit bank sampah sekolah dan 89 unit bank sampah milik instansi.

Keterlibatan Bank Sampah Malang didorong oleh tanggung jawab untuk membantu menyelesaikan permasalahan yang ada di sekitar mereka dengan pengalaman yang mereka punya. Pada tahun 2013, Bank Sampah Malang berhasil mengelola sebanyak 2,5 ton sampah (Bachtiar, 2014:132), sedangkan pada tahun 2019 Bank Sampah Malang berhasil mengelola sampah sebanyak 4,5 ton sampah. Kenaikan jumlah sampah yang berhasil dikelola oleh Bank Sampah Malang membuktikan bahwa Bank Sampah Malang cukup efektif dalam memfasilitasi masyarakat, pemerintah dan swasta untuk mengurangi sampah yang dibawa ke TPA Supiturang. Begitu pula pengetahuan masyarakat terkait dengan pengelolaan sampah semakin meningkat, sehingga masyarakat lebih peduli terhadap sampah yang 
masyarakat hasilkan sehari-hari. Hal tersebut membuktikan bahwa masyarakat memiliki peran besar dalam pengurangan sampah yang dibawa ke TPA Supiturang.

Dalam Bank Sampah Malang masyarakat memiliki peran sebagai berikut. Pertama, masyarakat ikut mendukung berdirinya Bank Sampah Malang dengan menjadi nasabah Bank Sampah Malang. Kedua, masyarakat bersedia menjadi trainer yang mengajari nasabah yang lain untuk membuat kerajinan dari sampah. Trainer tersebut berkumpul dalam sebuah organisasi yaitu PANAH BSM. Ketiga, menjadi pengurus bank sampah unit. Keempat, membeli kerajinan hasil kerajinan Bank Sampah Malang dan pengurus bank sampah unit. Kelima, nasabah juga membeli sampah yang berasal dari nasabah yang lain sesuai dengan kebutuhan nasabah, seperti misalnya koran dan kardus. Keenam, pendiri Klinik Asuransi Sampah Indonesia Medika. Ide untuk mendirikan Klinik Asuransi sampah ini pada mulanya berasal dari penelitian-penelitian yang telah dilakukannya, selain itu terinspirasi dari kejadian anak pemulung yang meninggal yang diakibatkan oleh penyakit diare dan karena biaya kesehatan yang mahal orang tuanya tidak mampu untuk membawa anak tersebut untuk berobat. Dari sinilah lahir Klinik Asuransi Sampah Indonesia Medika yang membawa misi setiap orang bisa mendapatkan akses pelayanan kesehatan dengan biaya yang terjangkau.

Masyarakat yang ingin bergabung menjadi pasien Klinik Asuransi Sampah cukup dengan cara sederhana, masyarakat membawa sampah kardus, plastik, botol, dan lain sebagainya yang dihargai Rp. 10.000,00 untuk membayar asuransi tiap bulannya. Asuransi tersebut digunakan untuk kontrol rutin, pencegahan sakit, pengobatan bagi pasien, serta rehabilitasi bagi nasabah yang baru sembuh dari sakit. Klinik Asuransi Sampah tersebut mampu membiayai dirinya dengan perputaran uang asuransi yang diberikan oleh pasien. Sampah tersebut dibawa ke Bank Sampah Malang untuk diolah kembali, hasil dari penjualan sampah tersebut digunakan untuk membeli obat dan membiayai layanan kesehatan.

CSR PT PLN terlibat di Bank Sampah Malang, karena memiliki visi dan misi yang berfokus pada lingkungan, sehingga terlibat di Bank Sampah Malang dengan tujuan mengurangi sampah yang ada di Kota Malang. Adanya Bank Sampah Malang membuat CSR PT. PLN merasa dapat membantu melestarikan lingkungan. CSR PT. PLN secara memberikan dukungan pada program dan kegiatan yang diselenggarakan oleh Bank Sampah Malang. CSR PT. PLN bersama-sama Pemerintah Kota Malang dan masyarakat Kota Malang berpartisipasi di Bank Sampah Malang dengan tujuan untuk mengurangi sampah yang di bawa ke TPA Supiturang dan juga ikut serta dalam memberdayakan masyarakat Kota Malang.

Dalam Bank Sampah Malang, CSR PT. PLN memiliki peran sebagai berikut, Pertama, CSR PT. PLN memberikan bantuan kepada Bank Sampah Malang sebesar 280 juta Bantuan tersebut digunakan untuk biaya operasional awal Bank Sampah Malang. Bantuan tersebut diberikan pada saat acara Rapat Kerja Nasional Bank Sampah ke-2 pada tanggal 2-3 November 2012 di Kota Malang. Kedua, CSR PT. PLN memberikan bantuan secara rutin kepada Bank Sampah Malang untuk menunjang kegiatan operasional sehari-hari Bank Sampah Malang. Bantuan tersebut dapat dijelaskan dalam tabel 1: 
Tabel 1.

Bantuan CSR PT. PLN kepada Bank Sampah Malang

\begin{tabular}{cl} 
Tahun Bantuan & \multicolumn{1}{c}{ Jenis Bantuan } \\
\hline 2012 & 1 unit pickup \\
2013 & Pelebaran area gedung \\
2014 & 1 unit pickup \\
2015 & Renovasi Kantor dan 1 unit Truck \\
2016 & Program Kemitraan ( Beli 1 Unit Pick Up) \\
2017 & Mesin Pencacah dan Timbangan \\
2018 & Gathering Nasabah \\
2019 & Seragam dan Rebranding Bank Sampah Unit, \\
& Pembuatan Website, CCTV, Mesin Jahit Daur \\
& Ulang \\
\hline
\end{tabular}

Sumber: CSR PT. PLN Distribusi Jawa Timur (2019)

Ketiga, CSR. PT. PLN melakukan pembinaan manajerial kepada karyawan Bank Sampah Malang. Berikut pernyataan dari Asisten Manager CSR. PT. PLN Distribusi Jawa Timur. Keempat, CSR. PT. PLN melakukan pendampingan kepada Bank Sampah Malang, dengan tujuan melihat perkembangan Bank Sampah Malang dan melihat kebutuhan yang paling diperlukan oleh Bank Sampah Malang. Kelima, CSR PT. PLN turut mempromosikan Bank Sampah Malang agar semakin memiliki banyak nasabah. CSR PT. PLN bekerja sama dengan Produksi Film Negara untuk membuat film terkait Bank Sampah Malang. Keenam, CSR PT. PLN juga mengajak para influencer untuk mempelajari kegiatan daur ulang sampah di Bank Sampah Malang. Influencer ini nantinya akan mempromosikan Bank Sampah Malang di media sosialnya, dengan mengedukasi masyarakat di media sosial bahwa sampah dapat di daur ulang menjadi sesuatu yang bernilai. Ketujuh, pada tahun 2011, CSR PT. PLN memberikan bantuan keuangan untuk pengembangan bank sampah unit sebesar Rp 58.000.000,00 Bantuan tersebut diberikan kepada Bank Sampah Unit Gurih. Uang sebesar Rp 58.000.000,00 tersebut kemudian digunakan untuk merenovasi bangunan Bank Sampah Unit Gurih dan membantu warga Kampung Terapi untuk membuat tempat sampah serta membeli seragam untuk 100 warga di Kampung Terapi.

Selama penulis berkomunikasi dengan narasumber, narasumber menyampaikan informasi dengan terus terang (bloko suto). Intonasi narasumber kepada penulis terdengar bernada semangat. Dalam berkomunikasi narasumber menyampaikan gagasan secara lugas dan ekspresif, sehingga mampu mengungkapkan maksud secara tepat. Hal tersebut sesuai dengan apa yang dikatakan oleh Siti Zuhro, bahwa dalam menyampaikan aspirasinya masyarakat Jawa Timur pada umumnya terbiasa menyampaikan secara terang-terangan dan bahkan terkesan keras (Zuhro, 2009:44). Masyarakat berharap agar pada tahun 2020 Kota Malang bisa menjadi bersih dan bebas dari sampah. Tujuan utama masyarakat dalam menangani sampah adalah agar Kota Malang menjadi bersih dan lebih tertata. Hal tersebut dikonfirmasi oleh pengurus Bank Sampah Unit Gurih, bahwa masyarakat bekerja sama untuk memperindah wilayahnya dengan batu terapi dan bunga.

Hal tersebut menunjukkan ciri khas masyarakat Budaya Arek, subkulture Budaya Arek Jawa Timur yang memiliki ciri khas terbuka, ekspresif, dan bloko suto (terus terang). Masyarakat Kota Malang memegang teguh filosofi Ojrek Bareng yang mendorong masyarakat untuk bekerja sama dengan Pemerintah dan Swasta dalam menangani masalah sampah di Kota Malang. Filosofi Ojrek Bareng ini tercermin dari ungkapan masyarakat Kota Malang dalam menangani permasalahan publik yaitu sengkuyung seduluran (semangat 
persaudaraan), ewuh pakewuh (perasaan tidak enak), dan tanpo pamrih (tanpa pamrih). Studi ini menolak teori Everyday Makers yang dikatakan oleh Henrik Bang dan Eva Sorensen, bahwa yang mendorong keterlibatan masyarakat dalam menyelesaikan permasalahan publik adalah sikap apati masyarakat terhadap Pemerintah. Sebaliknya, studi ini menemukan bahwa Ojrek Bareng sebagai bentuk antusiasme aktor nonpemerintah, yaitu masyarakat dalam menyelesaikan masalah sampah lewat Bank Sampah Malang.

\section{E. PENUTUP}

Dalam teori Governance kajian ini memperkuat Decentered Theory. Tindakan yang dilakukan oleh masyarakat bergantung pada keyakinan yang mereka pegang. Keyakinan itu dipengaruhi oleh tradisi atau kepercayaan masyarakat. Masyarakat Kota Malang memegang teguh filosofi Ojrek Bareng yang mendorong masyarakat untuk ikut serta dalam menangani masalah sampah bersama pemerintah dan swasta. Namun, studi ini mendebat teori Everyday Makers yang dikatakan oleh Bang dan Eva, bahwa yang mendorong keterlibatan masyarakat dalam menyelesaikan permasalahan publik adalah sikap apati masyarakat terhadap Pemerintah. Sebaliknya, studi ini menemukan bahwa Ojrek Bareng sebagai bentuk antusiasme aktor non pemerintah yaitu masyarakat dalam menyelesaikan masalah sampah lewat Bank Sampah Malang. Sikap antusias masyarakat Kota Malang ini dilandasi oleh Budaya Arek yang mendorong masyarakat untuk bekerja sama dengan Pemerintah dan Swasta dalam menangani masalah sampah di Kota Malang yaitu filosofi Ojrek Bareng. Filosofi Ojrek Bareng tercermin dari ungkapan masyarakat dalam menangani permasalahan publik, yaitu sengkuyung seduluran (semangat persaudaraan), ewuh pakewuh (perasaan tidak enak), dan tanpo pamrih (tanpa pamrih). Sikap sengkuyung seduluran ditunjukkan dengan perilaku masyarakat untuk bersama-sama mengumpulkan sampah dengan tujuan untuk memperindah lingkungan di sekitar wilayahnya, sikap ewuh pakewuh ditunjukkan oleh nasabah Bank Sampah Malang Unit kepada pengunjung yang datang untuk mengunjungi Kampung Terapi dan sikap tanpo pamrih masyarakat ditunjukkan dengan bersedia menjadi relawan yang bersedia mengorbankan biaya dan pikiran untuk menjadi pengurus bank sampah unit. Serta rela mengorbankan waktu dan tenaga untuk mengumpulkan sampah yang telah dipilah oleh masyarakat Kota Malang.

Setiap aktor governance memiliki peran yang begitu dominan dalam Bank Sampah Malang. Pemerintah Kota Malang memiliki peran sebagai berikut. Pertama, membantu Bank Sampah Malang dalam pengurusan perijinan pasca pendirian Bank Sampah Malang. Kedua, memberikan bantuan dan fasilitas kepada Bank Sampah Malang. Ketiga, membantu pemasaran hasil kerajinan Bank Sampah Malang serta membeli hasil kerajinan Bank Sampah Malang. CSR PT PLN memiliki peran sebagai berikut. Pertama, memberikan pembinaan manajerial. Kedua, memberikan bantuan fasilitas kerja dan fasilitas transportasi yang menunjang kegiatan operasional Bank Sampah Malang. Ketiga memberikan pelatihan yang menunjang kegiatan operasional Bank Sampah Malang. Masyarakat memiliki peran sebagai berikut. Pertama, menjadi trainer yang mengajari nasabah yang lain untuk membuat kerajinan dari sampah. Kedua, membeli sampah dari Bank Sampah Malang. Ketiga, Pendiri Klinik Asuransi Sampah Indonesia Medika. Keempat, ikut serta mendirikan Bank Sampah Malang unit sekaligus juga berperan dalam kegiatan operasional Bank Sampah Malang unit. Dampak dari adanya Bank Sampah Malang ini tidak hanya sekedar untuk mengurangi sampah yang terkumpul di gerobak sampah, namun juga dapat memberdayakan masyarakat dan menguatkan peran perempuan dalam skala rumah tangga maupun dalam lingkup komunitas nasabah Bank Sampah Malang dan nasabah Bank Sampah Malang unit. 
Rekomendasi untuk Bank Sampah Malang, adalah sebagai berikut. Pertama, adanya insentif/uang/hadiah tambahan untuk memicu semangat pengurus bank sampah unit. Kedua, adanya bingkisan bagi pengurus bank sampah unit pada setiap lebaran. Ketiga, Bank Sampah Malang sebagai induk memiliki cabang pada setiap kecamatan agar memudahkan atau mengefektifkan pendistribusian sampah dari bank sampah unit. Keempat, pematokan harga sampah tidak seperti saat ini yang harganya naik turun mengikuti harga pasar. Hal ini untuk menutupi fluktuasi harga sampah pemerintah bisa menghibahkan uang untuk menutupi fluktuasi harga sampah ini. Hal ini perlu untuk kepercayaan bagi nasabah bank sampah unit kepada pengurus bank sampah unit.

\section{DAFTAR PUSTAKA}

Abdillah, A. (2007). Budaya Arek Suroboyo. Tesis S-2 Universitas Airlangga Surabaya. Arief, S. (2013). Pengelolaan Sampah Malang Raya Menuju Pengelolaan Sampah Terpadu yang Berbasis Partisipasi Masyarakat. Jurnal Humanity, 8(2), 195-208.

Bachtiar, H. (2014). Pengembangan Bank Sampah Sebagai Bentuk Partisipasi Masyarakat Dalam Pengelolaan Sampah (Studi Pada Koperasi Bank Sampah Malang). Jurnal Administrasi Publik Mahasiswa Universitas Brawijaya, 3(1), 128-133.

Badan Pusat Statistik. (2016). Kota Malang dalam Angka. Malang: CV. Bima Mitra Mandiri. Badan Pusat Statistik. (2019). Statistik Daerah Kota Malang 2019. Malang: Badan Pusat Statistik.

Bang, Hendrik Paul. (2009). Political community: The blind spot of modern democratic decision-making. British Politics. https://doi.org/10.1057/bp.2008.38

Bang, Hendrik Paul. (2010). Everyday makers and expert citizens: Active participants in the search for a new governance. In Public Management in the Postmodern Era: Challenges and Prospects. https://doi.org/10.4337/9781849808873.00017

Bang, Hendrik Paul., \& Eva, Sorensen. (1999). The Everyday Maker: A New Challenge to Democratic Governance. Administrative Theory \& Praxis, 21(3), 325-341. https://doi.org/10.1080/10841806.1999.11643381

Bank Sampah Malang. (2018). Bank sampah malang dan wisata lingkungan berbasis masyarakat. Retrieved from http://www.banksampahmalang.com/download/Materi_Bank_Sampah_dan_Wisata_L ingkungan.pdf

Bevir, M. (2012). Encyclopedia of Governance. In Encyclopedia of Governance. https://doi.org/10.4135/9781412952613

Bochel, C., Bochel, H., Somerville, P., \& Worley, C. (2008). Marginalised or Enabled Voices? 'User Participation' in Policy and Practice. Social Policy and Society, 7(2), 201-210. https://doi.org/10.1017/s1474746407004150

Dalton, R. J. (2008). Citizenship norms and the expansion of political participation. Political Studies, 56(1), 76-98. https://doi.org/10.1111/j.1467-9248.2007.00718.x

Fenwick, J., \& McMillan, J. (2010). Public management in the postmodern era: Challenges and prospects. In Public Management in the Postmodern Era: Challenges and Prospects. https://doi.org/10.4337/9781849808873

Goenawan, N.A., Kuntjara, A. P., \& Pratama, R. (2016). Perancangan Buku Ilustrasi tentang Fenomena Budaya Arek Suroboyo. Jurnal Desain Komunikasi Visual Adiwarna. Retrieved from https://media.neliti.com/media/publications/87411-ID-none.pdf

Goldsmith, S., \& Eggers, W. D. (2004). Governing By Network The New Shape of the Public Sector. Washington, DC.

Hakim, A. (2017). Menteri LHK beri penghargaan pengelolaan sampah terbaik. Retrieved 
from

Www.antaranews.com website:

https://www.antaranews.com/berita/615186/menteri-lhk-beri-penghargaanpengelolaan-sampah-terbaik

Hanggoro, W. P. (2016). Bahasa Walikan sebagai Identitas Arek Malang. Etnografi, XVI(1), 23-30.

Hariyanto, P. (2017). Bank Sampah Binaan PLN terbaik 2017. Retrieved February 12, 2019, from www.ekbis.sindonews.com website: https://ekbis.sindonews.com/read/1186015/34/bank-sampah-binaan-pln-terbaik-20171488860969

Newman, J. (2005). Remaking governance: Peoples, politics and the public sphere. Remaking Governance: Peoples, Politics and the Public Sphere, 1-226. https://doi.org/10.1332/policypress/9781861346407.001.0001

Prasetyo, A., \& Arifin, M. Z. (2017). Analisis Biaya Pengelolaan Limbah Makanan Restoran. Jakarta: Indocamp.

Purwanto, I., Destiani, D., \& Partono, P. (2012). Perancangan Sistem Informasi Transaksi Tabungan Bank Sampah Garut. Jurnal Algoritma Sekolah Tinggi Teknologi Garut, 9(31), 1-12.

Putra, M. E. (2012). Malangnya Kota Malang. Retrieved December 13, 2019, from www.pirac.org website: http://www.pirac.org/2012/06/06/malangnya-kota-malang/

Ratiabriani, N. M., Bagus, I., \& Purbadharmaja, P. (2016). Partisipasi Masyarakat. Jurnal Ekonomi Kuantitatif Terapan.

Setyono, K. (2019). Bank Sampah Lahir di Yogyakarta, Sukses di Kota Malang. Retrieved November 29, 2019, from www.gatra.com website: https://www.gatra.com/detail/news/454581/gaya-hidup/bank-sampah-lahir-diyogyakarta-sukses-di-kota-malang

Sujiyanto. (2016). Analisis Pengelolaan Sampah Di Bank Sampah Malang. Jurnal Ilmu Sosial Dan Politik, 5(3), 115-122.

Sungkowati, Y. (2019). Arek Culture In Literary Works. Jurnal International Seminar on Languages, Literature, Arts and Education (ISLLAE), 1(1). https://doi.org/doi.org/10.21009/ISLLAE.01126

Utami, E. (2013). Buku-Panduan-Sistem-Bank-Sampah-10-Kisah-Sukses-Ina-Id_Tcm1310514974_Id.Pdf. Retrieved from https://www.unilever.co.id/id/Images/buku-panduansistem-bank-sampah-10-kisah-sukses-ina-id_tcm1310-514974_id.pdf

Zuhro, R. S. (2009). Demokrasi Lokal: Perubahan dan Kesinambungan Nilai-Nilai Budaya Politik Lokal di Jawa Timur, Sumatera Barat, Sulawesi Selatan dan Bali. Yogyakarta: Penerbit Ombak. 
